\title{
Türkçenin Yabancı Dil Olarak Öğretiminde Bir Materyal Çalışması: Temalara Uygun Şarkılar Oluşturma
}

\section{Nurdan Gürel ${ }^{1 *}$}

Geliș tarihi: 13.03.2019

Kabul tarihi: 26.03.2019

\section{Atıf bilgisi:}

Uluslararası Bilimsel

Araștırmalar Dergisi (IBAD)

Cilt: $4 \quad$ Sayı: 2

Sayfa: 305-321 Yll: 2019

Dönem: Yaz

This article was checked by Turnitin Similarity Index $26 \%$

${ }^{1}$ Türkiye, nrdnflz@gmail.com,

ORCID ID 0000-0003-0622-7161

* Sorumlu yazar

\begin{abstract}
ÖZ
$\mathrm{Bu}$ çalışmada Türkçenin yabancı dil olarak öğretiminde kullanılmak üzere bir materyal geliştirme çalışması yapılmıştır. $\mathrm{Bu}$ amaçla hazırlanan materyal, temalara uygun olarak bestelenen beş adet özgün şarkıdan oluşmaktadır. $\mathrm{Bu}$ şarkılarda A1 ve A2 dil seviyelerine göre belirlenen çeşitli dil bilgisi konuları, dil becerileri ve temel söz varlığına (gündelik dilde kullanılan kalıp ifadeler gibi) yer verilmiştir. Ayrıca her şarkıda belirli bir tema işlenmiştir. Tüm bu temalar belirlenirken Avrupa Ortak Öneriler Çerçevesi (AOÖÇ)'ndeki yeterliklerden yararlanılmıştır. Bestelenen şarkılarda tekrar eden ifadeler öğrencilerin öğrenmeleri için amaçlanan kelimeler ve kelime kalıplarından oluşmaktadır. Geliştirilen materyallerde kullanılan cümleler ve kelimeler öğrencilerin öğrendiklerini pekiştirmesi, konuların daha anlaşılır ve akılda kalıcı olması için etkinliklerle zenginleştirilerek şarkıların anlaşılma durumu yapılan uygulamalarla sorgulanmıştır. Çalışma sonucunda yabancılara Türkçe öğretimi alanında kullanılabilecek 5 adet özgün materyal ve bunlara yönelik etkinlikler ortaya konmuştur.
\end{abstract}

Anahtar Kelimeler: Türkçe eğitimi, yabancı dil olarak Türkçe öğretimi, şarkı, materyal çalışması, dil öğretim düzeyleri. 


\section{A Material Development Study for Teaching Turkish as a Foreign Language: The Use of Suitable Songs}

\section{Nurdan Gürel ${ }^{1 *}$}

First received: 13.03 .2019

Accepted: 26.03.2019

\section{Citation:}

Journal of the International Scientific Research (IBAD)

\section{Volume: 4 Issue: 2}

Pages: 305-321 Year: 2019

Session: Summer

This article was checked by Turnitin. Similarity Index $26 \%$

${ }^{1}$ Türkiye,nrdnflz@gmail.com

ORCID ID 0000-0003-0622-7161

* Corresponding Author

\begin{abstract}
In this study, a material development study was carried out for teaching Turkish as a foreign language. The material prepared for this purpose is eight original songs composed according to the theme. In these songs, various linguistic knowledge, language skills, and basic vocabulary (such as expressions used on every day occasions), which are determined according to the language levels A1 and A2, are included. In addition, certain themes are processed in each song. All of these themes were used while the qualifications in the European Language Common Framework Program were utilized. Repetitive expressions in composing songs consist of words and word patterns intended for students learning. Cues and words used in the developed materials were enriched by activities in order to reinforce the learning of the students and to make the subjects more understandable and memorable, and the understanding of the songs was questioned with the applications.
\end{abstract}

Keywords: Turkish education, Teaching Turkish as a foreign language, song, material study, language teaching levels. 


\section{GíRiş}

İnsanın ana dili haricinde öğrenmeyi hedeflediği dil, hedef dil veya ikinci dil olarak adlandırılmaktadır (Barın ve Güzel, 2013, s. 228). İnsanların yabancı dili öğrenme sebepleri; göç, eğitim, evlilik, akademik başarı, ticari, kültürel, sosyal etmenler, diğer insanlarla iletişim kurma olarak çeşitlenmektedir. Bu sebepler içerisinde yer alan en önemli unsurlardan birisi siyaset ya da dünya üzerindeki siyasi reformlardır. Örneğin pek çok Avrupa ülkesi için üst bir kuruluş olan ve oldukça geniş çapta çalışmalar yürüten Avrupa Konseyi, belirli dil politikalarına sahip olduğunu ve bu politikalar doğrultusunda üye ülkelerde de dil öğretimi yapılması gerektiğini, 2001 yılında uygulamaya koyduğu "Diller İçin Avrupa Ortak Başvuru Metni" (AOÖÇ) ile belirtmiştir (CEFR, 2001; MEB, 2009). Çerçeve içerisinde konseyin dil politikası amaç ve hedefleri şunlardır:

- Avrupa'daki dil ve kültür çeşitliliğinin zengin mirasının korunması ve geliştirilmesi gerekir. Dil ortak bir kaynaktır ve bu çeşitliliği iletişim yolunda bir engel olmaktan çıkarıp karşı1ıklı bir zenginleşme ve anlayış hâline getirmek için eğitim alanında büyük çabaya ihtiyaç vardır.

- Avrupa hareketliliğini artırmak, ortak anlayış ve iş birliğini güçlendirmek, ön yarg1 ve ayrımcılığın üstesinden gelmek için farklı ana diline sahip Avrupalılar arasında iletişim ve etkileşimin kolaylaştırılması gerekmektedir. Bu ancak modern Avrupa dillerini daha iyi bilmekle mümkün olacaktır.

- Üye ülkeler, modern dil öğretim ve öğreniminde ulusal ilkeleri kabul ettiği ya da geliştirdiği takdirde mevcut ilkelerindeki iş birliği eşgüdümde uygun düzenlemeleri yaparak Avrupa düzeyinde daha büyük bir yakınlaşma elde edebileceklerdir (MEB, 2009, s. 2).

Dil çeşitliliğini iletişim yolunda bir engel olmaktan çıkarmak, Türkçenin Avrupa'da ve diğer ülkelerde kullanılmasını sağlamak bu açıdan bakıldığında oldukça önemlidir. Ülkemize gelip Türkçe öğrenmek isteyen ve dünya üzerinde (çeşitli enstitülerde ve internet tabanlı eğitim ile) yabancı dil öğrenmek isteyen yabancıların sayısı da günden güne artmaktadır.

Dil öğrenme talebinin giderek artması, Türkçenin yabancılara öğretimi ile ilgili çalışmaların sayısının ve niteliğinin de çoğalmasını sağlamıştır. Ayrıca yabancı dil olarak Türkçe öğretmenin önemi, devlet politikalarının da yönlendirici etkisiyle birçok kurum ve kuruluşun faaliyete geçilmesini sağlamıştır. Bu kurum ve kuruluşlar, sürekli gelişen dil öğretim stratejileri, yöntemleri 1şığıında yabancı dil olarak Türkçe öğretimi alanında çalışmalarda bulunmaktadır (Demir ve Açık, 2011, s. 52).

Türkçenin yabancı dil olarak öğretiminin nasıl olması konusu çeşitli başlıklar altında incelenmektedir. Bunlar öğretim elemanlarının sahip olması gereken vasıflar, ders işleme tekniğinde dikkat edilmesi gerekenler, sınıf içinde uygulamalar, alfabe öğretiminde harfler ve örnekleri, sözcük öğretimi, kelimelerden cümleye geçiş örnekleri, zamanların kavratılması ve diğer dil bilgisi kalıpları, AOÖÇ’de yer alan yabancı dil seviyeleri ve metin seçimidir. Elbette sıralanan unsurların işlerliği AOÖÇ'de açıklanan unsurlar ve belirlenen yeterliklere göre şekillenmektedir. Bu metinde üç temel düzeyden bahsedilmektedir. Bu düzeyler şu şekilde gösterilebilir: 

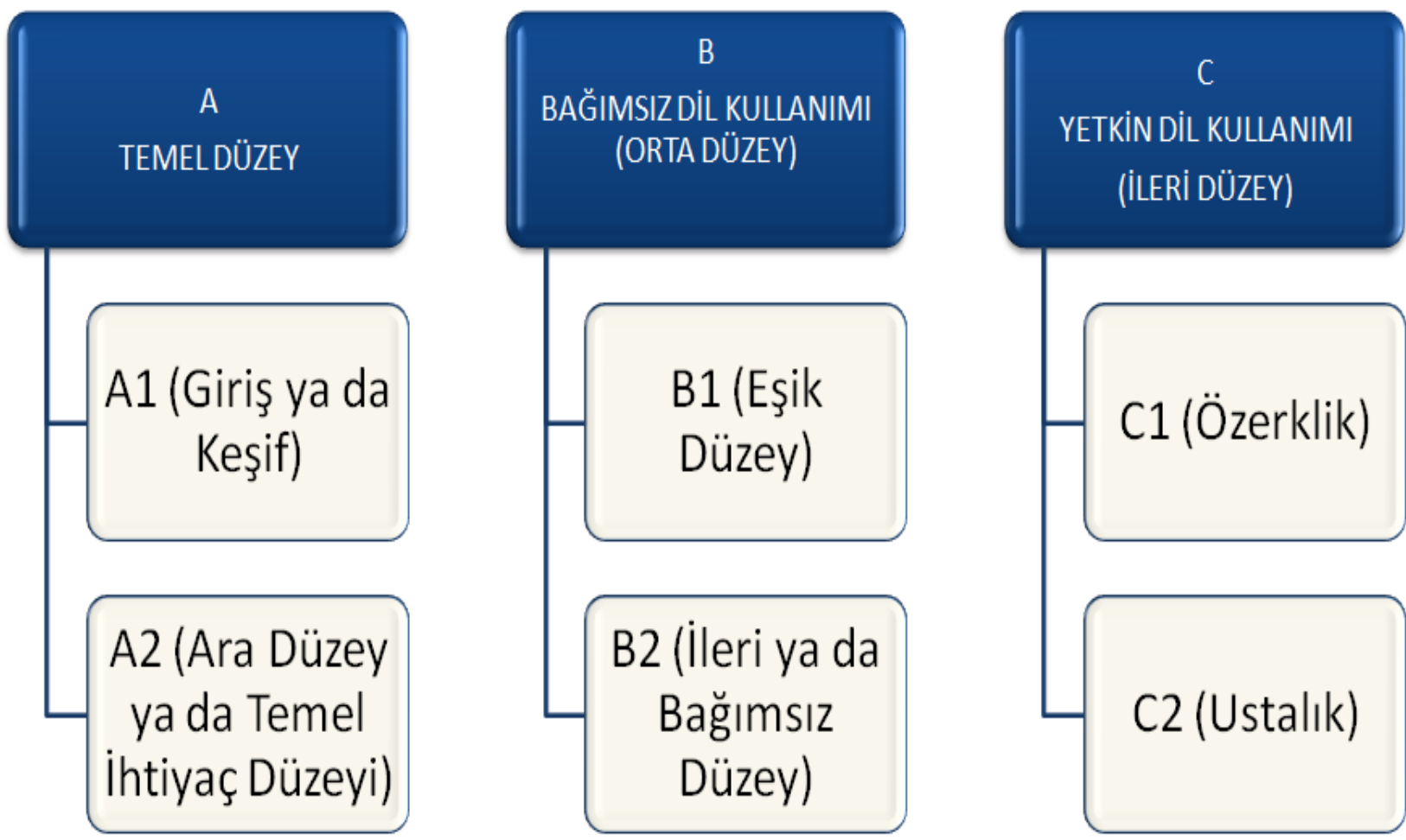

\section{Şekil 1. AOÖÇ’deki Dil Düzeyleri}

Şekil 1'de görüldüğü gibi A1 (Elementary) - A2 (Pre-intermediate) temel düzeyi (Basic user) ifade ederken, B1 (Intermediate) - B2 (Upper Intermediate) orta düzeyi (Independent user) açıklamaktadır. CI (Expert) - C2 (Mastery) ise yetkin dil kullanımı (Proficient user) anlamına gelmektedir. A, öğrencinin hedef dille tanıştığı düzey olarak nitelenebilir. Bu nedenle A seviyesindeki öğrencilerin Türkçeyi eğlenerek öğrenmesini sağlamak, onların öğrendikleri dile karşı olumlu tutum geliştirmelerine yardımcı olacaktır denilebilir. Dolayısıyla dil öğretim çalışmalarında müzikten yararlanmak, öğrenme sürecini kolaylaştırıcı bir yöntem olarak kullanılabilir.

\section{MÜZİĞİN YABANCI DİL ÖĞRETIMINDEKİ ETKILERİ}

Müzik; zihinsel gelişimi, motor gelişimi, dil gelişimi, iletişim ve farkında olma becerilerinin gelişimi, duygusal gelişimi ve yaratıcılığı olumlu yönde etkilemektedir (Temiz, 2011, s. 68). Bu durum yeni bir dil öğrenmede oldukça önemlidir ve yabancı dil öğretimini desteklemektedir.

Nörologların bulguları, müzik ve dil yapısının beynin aynı bölümünde işleme girdiğini gösterirken müzikal yapının ve dilsel sözdiziminin burada aynı paralelde yer aldığını bildirmektedir (Maess ve Koelsch, 2001). Yapılan araştırmalar dil öğreniminde her iki lobun da öğrenme faaliyetlerine katılması gerektiğini gösterir. Çünkü her iki lobun fonksiyonları birbirini tamamlamaktadır. Broca ve Wernicke alanlarının konuşmada ve anlamada önemli etkileri bulunmaktadır. Ancak beyinde konuşmanın gerçekleşmesi ve anlaşılmanın sağlanması için yalnız bu iki alanı düşünmemek gerekir. Dilin, beyinde hangi bilişsel beceriler ile bağlantıda olduğu henüz tam olarak bilinmemektedir. Şu andaki bilgilere göre etkin bir dil öğrenimi için beynin bütün alanlarını etkinleştirmek gerekmektedir (Köse, 2012, s. 5). Müziğin ve dil yapısının beynin sağ bölümünde işlemden geçtiğini, konuşma ve sözlü ifadenin ise sol bölümünde işlendiğini göz önünde bulundurulduğunda, şarkıları dinleyip incelemenin ve bunlar hakkındaki düşünceleri sözlü olarak ifade etmenin beynin her iki bölümünün de çalışmasına olanak tanıdığı söylenmektedir (Iudin-Nelson, 1997, s. 84).

Schellenberg (2001) müzik derslerinin dil derslerine katkısı üzerinde durmuş; Kolb (1996) ise "Öğrenmede Müzik Dili” adlı çalışmasında müziğin dil öğrenmede ve olumlu tutum geliştirmedeki 
önemini vurgulamıştır. Yurt içinde, Yılmaz (2006), Çilden (2001) ve Çelikkol (2007) müziğin ana dil üzerindeki etkileri üzerinde bazı çalışmalar yürütmüşlerdir. Yılmaz (2006), çocuk eğitiminde sözleri müzikle, ezgiyle söylemenin ve şarkılaştırmanın önemi üzerinde durmuş; müziğin dinleme becerisi kazandırdığını ve öğrencilerin dikkat sürelerinin uzamasını sağladığını ifade etmiştir. Çilden (2001) "Müzik, Çocuk Gelişimi ve Öğrenme" adlı çalışmasında günümüz eğitim koşullarından ve müziğin çocuk gelişimine katkılarından bahsederek müziğe, öğretim programının bir parçası olarak bakılması gerektiğini vurgulamıştır. Çelikkol (2007) ise müziğin ilköğretimde müzik eşliğinde öğrenilen kelime ve kelime gruplarının klasik yönteme göre daha başarılı olduğunu ortaya koymuş; öğrencilerde olumlu tutum geliştirme noktasında da Kolb'un (1996) çalışmasını destekler nitelikte bulgular elde etmiştir (Güney, Aytan ve Şengül, 2014. s. 123). Dil derslerinde müziğin kullanılması genellikle şarkılar yolu ile olmaktadır. Şarkılar ulaşılabilir, kolay pedagojik materyaller olmasının yanı sıra öğrencileri dinlendirir ve hareketlendirir, onların dikkatlerini derse vermelerini ve eğlenmelerini sağlar, sınıf atmosferini değiştirir, öğrenme durumları yaratır (Köse, 2012, s. 12).

Şarkı dilinin özellikleri de dil dersleri için ne kadar uygun materyaller olabileceğini göstermesi bakımından önemlidir. Bu özellikler şu şekilde sıralanabilir:

Açık seçiklik: Şarkıların dili sınırlı zaman dilimi içinde gerçekleşen, dil derslerinin hızlı temposunda, kavranabilecek açıklıkta olmakta, dil açısından öğrenim engeli oluşturmamaktadır.

Yoğunluk: Şarkıların her biri kapalı bir küçük dünya oluşturur ve nakarat tipi dizelerle sağlanan birçok tekrarı içerir. Bu tekrarlar genelde anlaşılması kolay ve akılda kalıcı dizelerdir. Şarkı dili somut sözcüklerle dolu belirli sayıda tümcelerden oluşur, anlatacaklarını basit, doğrudan, açıkça bir ifade kullanarak, bununla beraber yoğunluğu fazla, büyük bir hayal gücüne gönderme yaparak anlatır.

Uygunluk: Şarkılarda anlam iskeletini oluşturan anahtar sözcükler vardır ve bu sözcüklerle ilgili soru-yanıt oyunları, öğreneni şarkının anlam bütünlüğü konusunda bir fikir sahibi yapar. Bazen benzetmeler yoluyla bazen anlayarak bazen de sezerek uygunluk sağlayan elemanlar yardımıyla şarkının genel anlamı kolayca kavranabilir. Tüm bu çalışmalar müziği yabancı dil öğretiminde de ne kadar etkili olduğunu ve sınıf atmosferini olumlu yönde nasıl değiștirebileceğini göstermektedir (Ataseven, 1988, s. 193). Dil öğretiminde şarkıların kullanılması pek çok açıdan önemli ve etkili ise yabancılara Türkçe öğretiminde de şarkıların kullanılması dersi olumlu yönde etkileyebileceği düşünülebilir.

\section{YABANCILARA TÜRKÇE ÖĞRETIMINDE MATERYAL OLARAK ŞARKILARIN KULLANIMI}

Dil öğrenme sürecinde dinlemenin, konuşma yetisine göre iki kat, okuma yetisine göre dört kat, yazma yetisine göre ise beş kat daha fazla kullanıldığı belirtilmektedir (Lacorte ve Thurston, 2016, s. 49). Şarkılarla dil öğretiminde; öğretilen konunun pekiştirilmesi, dinleme becerilerinin geliştirilmesi, motivasyonun artırılması, öğrenilenlerin hatırlanması ve kelime öğretimindeki etkililiğin belirlenmesine yönelik yapılan araştırmalar değerlendirildiğinde, şarkıların öğrenci motivasyonunu önemli derecede artırdığı, sınıftaki stresi azaltarak öğrenmeyi kolaylaştırdığı, kelime öğretiminde büyük fayda sağladığı, öğrencilerin aktif katılımlarını gerçekleştirdiği ve sınıfa iletişimsel bir boyut kazandırdığı anlaşılmaktadır. Özellikle dinleme öncesi, sırası ve sonrasında yapılandırılmışsa öğrencinin konuyu daha iyi öğrenmesini sağladığı görülmektedir (Kömür, Saraç ve Şeker, 2005, s. 111-114). Sözgelimi öğrencilerin sınıfta bir şarkı eşliğinde alfabeyi, sayıları, sağı-solu veya vücudun bölümlerini şarkının ritmine göre fiziksel hareketler yaparak nasıl kolaylıkla öğrendikleri bilinmektedir (Dunlap ve Lowenthal, 2010, s. 3). Dolayısıyla öğrencilerin müzik ve şarkılar ile eğlenerek öğrendikleri ve bu sayede motivasyonlarının en üst seviyede olduğu söylenebilir. Ayrıca şarkılar sadece sınıf içinde değil, öğrencilerin evde veya bireysel öğrenme yapabildikleri her yerde kullanılabilen otantik materyallerdir. Yabancı dil öğrenirken de kullanılan otantik materyaller arasında önemli bir yere sahiptirler. Çoğunlukla ana dilini konuşan kişi tarafindan seslendirilen şarkılarda dile ait birçok kültürel öge ve ifade de bulunmaktadır. Böylece öğrenci sadece dinleme yapmamakta, aynı 
zamanda hedef dilin kültürüne ilişkin bilgisini de arttırmaktadır. Öğrenilen kelimelerin nasıl okunacağ1 ve telaffuz edileceği de şarkılar dinlenirken öğrenilebilmektedir (Yustiana, 2009, s. 3).

Şarkıyla öğrenim sürecinde rahatlamanın bir sonucu olarak bazı öğrenciler daha az tehdide maruz kaldıklarını hissetmektedir, bu da diğer egzersiz türlerinin çoğunda gözlenen "düşük motivasyon, yüksek endişe düzeyi ve öğrencinin düşük seviyedeki kendine güveni" yüzünden ortaya çıan zihinsel bariyerleri aşağı seviyeye çekmektedir (Krashen 1989, s. 10). Bu olumsuz etkilerin azalması sonucunda yabancı dil öğrencisinin motivasyon düzeyi yükselme imkânı bulabilecek, kendine daha çok güvenerek başarısını artıracaktır (Gökşenli, 2012, s. 19).

Şark1 sözleri notalarla söylendiği zaman ortaya şarkı çıkmaktadır. Notanın değeri, verilecek olan sesin uzunluğunu ve yüksekliğini belirleyen etkenlerden birisidir. Sözlü iletişimde de durum hemen hemen aynıdır. Dillerin de bir tınısı ve müziği olduğunu söylenebilir. Şarkı ile dilin müzikalini eğitmek mümkündür. Her öğretmenin şarkı söylemede becerikli ve güzel sesli olması beklenemez. Ancak ses band1, kaset ya da CD'lerden yararlanması mümkün olabilir (Demirel, 2014, s. 101). Aynı zamanda şarkıların yapısı gereği nakarat bölümlerinde sürekli tekrarlar yapılmaktadır. Bu tekrarlar dil gelişim sürecinde hızlı ilerlemeye ve akıcılık kazanmaya yardımcı olmaktadır. Şarkıların sağladığı bilinçsiz öğrenmeler ve duyuşsal boyutu dikkate alındığında şarkıların öğrenmede ne kadar güçlü olduğu anlaşılabilmektedir. Zaten çoklu zekâ kuramında müzikal zekâ türü dikkate alındığında, çok iyi planlanmış şarkılarla dolu bir dersin, dilsel becerileri harekete geçirerek olumlu öğrenme sonuçları doğurduğu daha iyi anlaşılmaktadır (Chen ve Chen, 2009, s. 17-18).

Öğrencilerin dil öğrenimine böylesine önemli ve olumlu katkıları olan şarkılar, yabancı dil sınıflarında aşağıdaki durumlarda öğretim programına dâhil edilebilir (Tancman, 2005, s.1):

1. Sınıfta işlenmiş bir konunun pekiştirilmesi,

2. Yeni kelimelerin öğretilmesi ve kullanılması,

3. Yeni bir dil bilgisi konusunun öğretilmesi veya kullanılması,

4. Kültürel bir olayın tanıtılmas1, 143).

5. Öğrencilerin yazınsal bir metne olan duyarlılığının artırılması (Yılmaz ve Güngör, 2014, s.

Şarkıların Türkçenin yabancı dil olarak öğretiminde kullanılması, öğrenim için gerekli ve birbirine bağlı birçok etmeni harekete geçirebilmektedir. Bütün dil becerilerinin pekiştirilebildiği bir şekilde hazırlanmış bir Türkçe şarkı dersi, birçok farklılığı da yanında getirebilmektedir. Öğrenciler, içerisinde müzik olan bir derse daha fazla ilgi gösterebilir ve olumsuz tavırlarında yumuşama olabilir ya da bu olumsuz tavırlar ortadan tamamen kalkması sağlanabilir. Bu tür materyaller öğrencilerin seviyelerine uygun şekilde hazırlanmalıdır. Bu şekilde hazırlanan bir materyal, motive olmuş bir öğrencinin başarıya ulaşmasını elbette olumlu yönde etkileyecektir. Başarıya ulaşan bir öğrenci kendine daha fazla güvenebilir. Kendine güven hissini geliştirmesine yardımcı olan derse karşı olumlu tavırlar geliştirmesi doğal bir sonuç olarak kabul edilebilir. Bu olumlu tavırlar bireyin akademik ve psikolojik olarak başarılı hissetmesinde önemli rol oynamaktadır. Bu döngü aşağıdaki şekille gösterilebilir: 


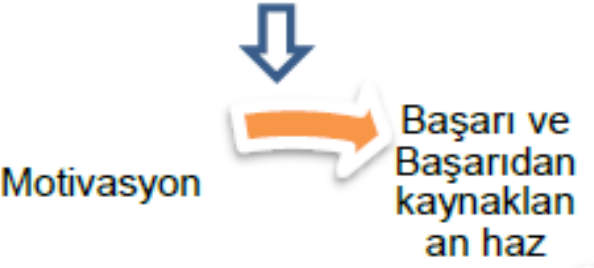

\section{Akademik ve \\ Psikolojik Bașarı}

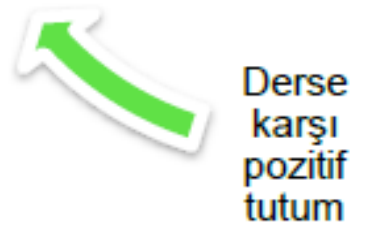

\author{
Kendine \\ güvenme \\ hissi
}

Şekil 2. Şarkı ile Yapılan Dersin Etki Döngüsü (Nişancı, 2013, s. 5)

Şekil 2'den de anlaşılacağı üzere yabancı öğrencinin Türkçe öğrenirken olumsuz bir tutum taşımasını veya kaygı düzeyinin artmasını önlemenin en etkin yollarından birinin öğretim sürecinde müzikten yararlanma olduğu söylenebilir.

Müziğin dil öğretiminde nasıl kullanılması gerektiği ve yapılan araştırmaların bulguları doğrultusunda bu çalışmanın amacı; çeşitli dil bilgisi konularını, kelimeleri ve kelime kalıplarını A1 ve A2 dil seviyelerini dikkate alarak temalara uygun olarak özgün beş adet şarkı bestelemek ve bu şarkılarda işlenen konuya uygun etkinlikler hazırlamaktır. Böylece yabancılara Türkçe öğretimi alanında kullanılabilecek özgün bir materyal ortaya konmuş olacaktır.

\section{ŞARKILARIN BESTELENME SÜRECI}

Yabancılara Türkçe öğretmek amacıyla bu çalışma için bestelenen şarkılar, öğretmek istediği dil kalıbı ve kelimeler açısından tek tek incelenmiştir. Ayrıca bu şarkılar tematik sınıflandırmaya göre ve A1 ve A2 dil seviyeleri dikkate alınarak gruplandırılmıştır.

Hangi konuların (öğretilecek dil bilgisi kalıpları ve kelimeler) şarkılar vasıtasıyla öğretileceği belirlenmiştir. Belirlenen konuların tema ayırımları yapıldıktan sonra da seviyelere uygun kullanılabilecek kelimeler, var olan dil öğretim setlerindeki kelime dizinleri dikkate alınarak belirlenmiştir.

Belirlenen kelimeler ve öğretilmesi hedeflenen dil bilgisi kalıplarına göre (prozodiye de uygun) besteler yapılmıştır. Yazılan güfteler, uzman görüşleri de alınarak bestelenmiştir.

$\mathrm{Bu}$ işlemler sırasında şarkıların tematik olarak sınıflandırılması ve güftelerin A1-A2 seviyesini yansıtmasına, prozodiye uygunluğuna, şiir kalıbına ve temaya uygunluğuna, melodilerin bütünlük içinde kulakta kalıcı olmasına, hafızaya kolay alınabilmesine dikkat edilmiştir.

Yapılan beş adet bestenin beşi stüdyo ortamında; keman, piyano, vurmalı çalgılar (perküsyon), yan flüt çalgıları kullanılarak kaydedilmiştir. Eğitim materyalini pekiştirmek ve desteklemek için bestelere ve öğretilmesi amaçlanan dil bilgisi ve kelimelere uygun etkinlikler oluşturulmuştur. 
Stüdyo ortamında kaydedilen beş adet şarkı ve bunlara yönelik hazırlanan etkinlikler, Bilkent Üniversitesi Yabanc1 Diller Koordinatörlü bünyesinde bulunan A1 (15 öğrenci) ve A2 (20 öğrenci) öğrencileri üzerinde denenmiştir. Anlaşılmayan şarkı sözü olup olmadığı, etkinliklerin içeriği yansıtıp yansıtmadığı gibi pek çok husus bu uygulamalar sırasından gözden geçirilerek uygulaması yapılan şark1 ve etkinliklere son şekli verilmiştir.

Bu şekilde tanışma teması altında; "Merhaba", sosyal etkinlikler teması altında; "Spor Yap, Zinde Kal", "Sosyal Hayatımı Hep Çok Severim", hava durumu teması altında " Bulutlar Hepimize Merhaba Diyor", hobiler ve ilgi alanları teması altında "Hobilerimi Çok Seviyorum", iletişim teması altında "İletişim Araçları", alışveriş teması altında "Haydi Alışveriş Yapalım”, insan ve toplum teması altında "Herkesin Bir Kişiliği Var" adlı bestelenen beş adet şarkı özgün materyal olarak kullanıma hazır hâle getirilmiştir.

\section{BULGULAR VE YORUM}

Bu bölümde bestelen şarkılar ile bu şarkılara yönelik hazırlanan etkinliklere yer verilmiştir.

Şarkı 1: Hobilerimi Çok Seviyorum

\begin{tabular}{|l|l|l|}
\hline \multicolumn{1}{|c|}{ Beceriler } & \multicolumn{1}{c|}{ Dil Bilgisi } & \multicolumn{1}{c|}{ Kelimeler } \\
\hline $\begin{array}{l}\text { Hobinin ne olduğunu } \\
\text { bilme }\end{array}$ & Kalıplaşmış adlar & Şark1 söylemek \\
Hobilerini söyleme & Evcil hayvan beslemek \\
Hobilerle ilgili kelimeleri & & Tenis oynamak \\
bilme & & Alışveriş Yapmak \\
& & Müzik dinlemek \\
& & Fotoğraf Çekmek \\
& & Satranç Oynamak \\
& & Bisiklet sürmek \\
\hline
\end{tabular}

Tema: Hobiler ve İlgi Alanları

Dil Bilgisi: Ad Tamlamaları

Amaç: Hobi Nedir? Ne İşe Yarar?

\section{HOBILERIMİ ÇOK SEVIYORUM (A1)}

Mesleğim dışında bazı işler yapıyorum.

Şarkı söylemek, evcil hayvan beslemek,

Tenis oynamak, alışveriş yapmak...

Biz bu işlere, hobi diyoruz. (2)

Seviyorum çok seviyorum

Hobilerimi çok seviyorum (Nakarat)

Mesleğim dışında bazı işler yapıyorum.

Müzik dinlemek, fotoğraf çekmek,

Satranç oynamak, bisiklet sürmek...

Biz bu işlere, hobi diyoruz. (2)

Seviyorum çok seviyorum.

Hobilerimi çok seviyorum (Nakarat)

Söz: Nurdan Gürel

Müzik: Nurdan Gürel 


\section{HOBILERIMI ÇOK SEVIYORUM}
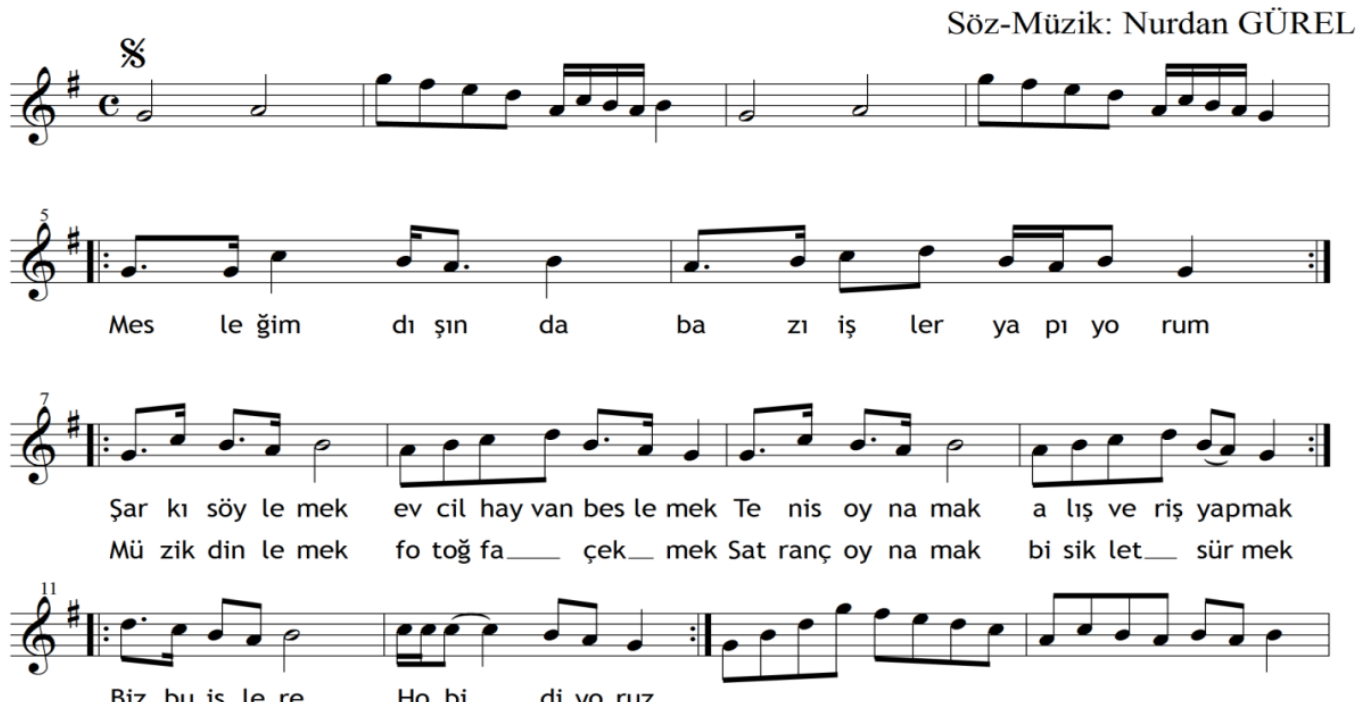

Biz bu iș le re Ho bi__ di yo ruz
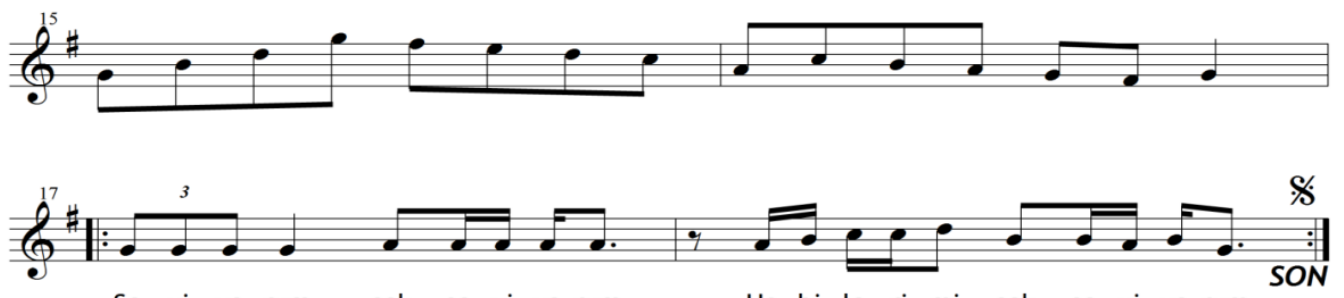

"Hobilerimi Çok Seviyorum" adlı bu şarkıda hobiler ve ilgi alanları teması işlenmiştir. Öğretilmesi amaçlanan dil bilgisi kalıbı ise A1 dil seviyesindeki öğrenciler için kalıplaşmış adlardır. Şarkının ilk cümlesi hobi kelimesinin anlamını açıklar niteliktedir. Şarkıda, hobi teması ile alakalı isimleri ve nelerin hobi olacağını ifade eden kelimelerin sık kullanımı öğrenimin daha kolay olmasını sağlayabilmektedir. "şarkı söylemek", "evcil hayvan beslemek", "tenis oynamak", "alışveriş yapmak", "müzik dinlemek", "fotoğraf çekmek", "satranç oynamak", "bisiklet sürmek" öğretilmesi amaçlanan kelimelerdir. Öğrenciler bu şarkıyı söyleyerek hobi kavramının anlamını, hobilerle alakalı kelimeleri, nelerin hobi olabileceğini ve kalıplaşmış adları öğrenebilirler.

\section{Şarkı 2: Alışveriş}

\begin{tabular}{|c|c|c|}
\hline Beceriler & Dil Bilgisi & Kelimeler \\
\hline $\begin{array}{l}\text { Alışveriş teması ile ilgili } \\
\text { kelimeleri öğrenir, } \\
\text { Zarf- fiil eklerinden - } \\
\text { (y)erek/arak cümleye kattığı } \\
\text { anlamını kavrar, } \\
\text { Ayrılma/uzaklaşma hal ekini } \\
\text { (-dan/-den) sezer. }\end{array}$ & $\begin{array}{l}\text {-(y) erek/arak } \\
\text { - dan, -den }\end{array}$ & $\begin{array}{l}\text { kazak, pantolon, ceket, } \\
\text { atk1, şapka, eldiven, elma, } \\
\text { patates, domates, soğan, } \\
\text { portakal, patlican, market, } \\
\text { pazar }\end{array}$ \\
\hline
\end{tabular}


Tema: Alışveriş

Dil Bilgisi: -(y) arak, -(y) erek

Amaç: Markete Gidelim Böylece /Bu Şekilde Alışveriş Yapalım. Markete Giderek Alışveriş Yapalım.

Cümleleri arasındaki anlam ilişkisini sağlayan ekin işlevini öğretmek.

\section{HAYDİ, ALIŞVERİŞ YAPALIM (A2)}

Haydi, alışveriş yapalım.

Çantamızı alarak, alışveriş yapalım. (2)

Bir kazak, bir pantolon, bir ceket...

Bir şapka, bir atkı, bir eldiven alalım. (2)

Markete giderek, alışveriş yapalım.

İhtiyaçlarımızı marketten alalım. (Nakarat)

Haydi, alışveriş yapalım.

Çantamızı alarak, alışveriş yapalım. (2)

1 kilo elma, 3 kilo patates, yarım kilo domates

2 kilo soğan 1 kilo portakal, 1 kilo patlıcan alalım. (2)

Pazara giderek, alışveriş yapalım.

İhtiyaçlarımızı pazardan alalım. (Nakarat)

Söz - Müzik: Nurdan Gürel
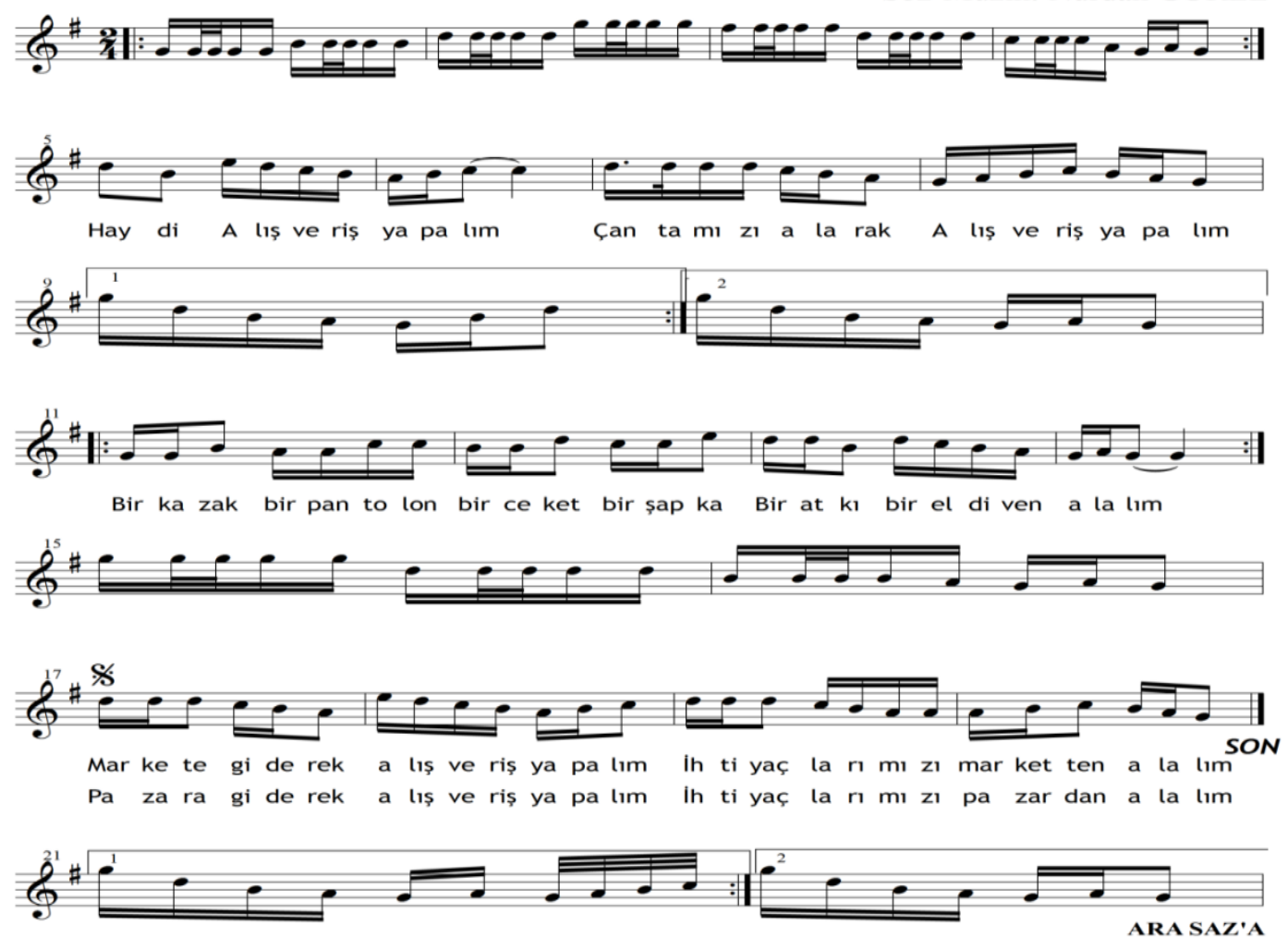

SAYFA -1- 


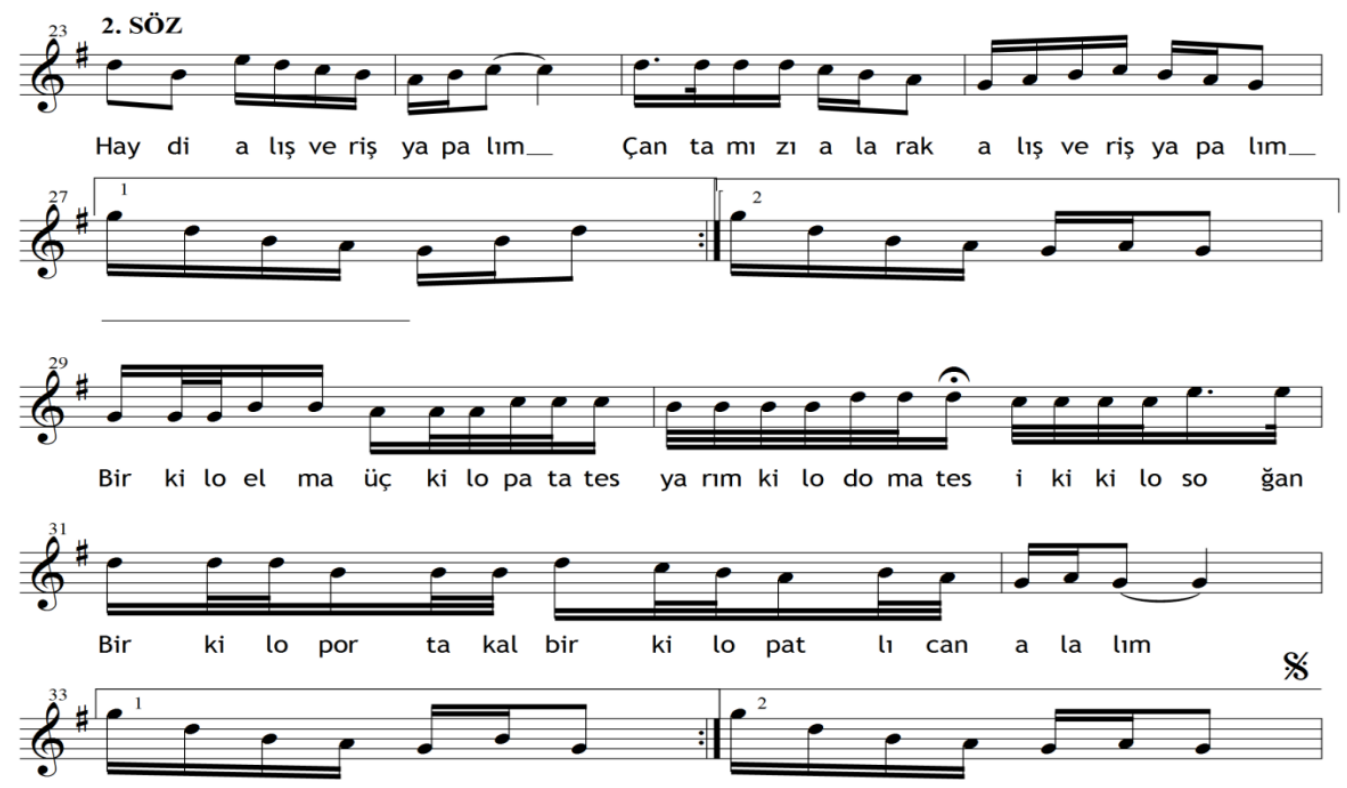

Bestelenen bu şarkıda A2 dil seviyesindeki öğrenciler, kullanılan alışveriş teması altında alışveriş ile ilgili kelimeleri (kazak, pantolon, ceket, atkı, şapka, eldiven, elma, patates, domates, soğan, portakal, patlıcan, market, pazar) öğrenmeleri ve zarf-fiil eklerinden (-y)erek/(-y)arak'ın cümleye kattığı anlamı fark etmelerini sağlamak amaçlanmıştır. Öğrenciler bu ek ile zamansal olarak bağlantılı cümleleri anlamı değişmeden nasıl kullanabileceklerini öğrenebilirler. Tekrar eden ifadeler amaçlanan kelimeleri ve kelimelerin öğrenilmesi hedeflenen kelimelerin telaffuzunu daha kolay öğrenmeleri için oluşturulmuştur. $\mathrm{Bu}$ durum aynı zamanda öğrencilerin konuşma becerilerine de katk1 sağlayabilmektedir. Şarkıda kullanılan cümleler ve kelimeler öğrencilerin öğrendiklerini pekiş̧irmesi daha anlaşılır ve akılda kalıcı olması için etkinliklerle zenginleştirilmiştir.

Şarkı 3: Sosyal Hayatımı Hep Çok Severim

\begin{tabular}{|l|l|l|}
\hline \multicolumn{1}{|c|}{ Beceriler } & \multicolumn{1}{c|}{ Dil Bilgisi } & \multicolumn{1}{c|}{ Kelimeler } \\
\hline Geniş zamana ait kelime & Geniş zaman kelime kalıpları & Genellikle \\
kalıplarını öğrenir, & Her zaman \\
Geniş zaman kalıplarıla ilgili & & Bazen \\
kelimeleri cümle içinde & Çoğu zaman \\
kullanır. & & Ara sıra \\
\hline
\end{tabular}

Tema: Sosyal Etkinlikler

Alt Tema: Sinema - Tiyatro- Konser

Dil Bilgisi: Geniş zaman ifadelerinin cümleye kattığı anlamı öğretmek. 
SOSYAL ETKİNLIK (A2)

Film izlemeyi her zaman severim.

Arkadaşlarımla hep film izlerim.

Bazen kardeşimle tiyatroya giderim.

Sosyal hayatımı pek çok severim.

Çoğu zaman işime bisikletle giderim.

Ara sıra yürürüm, müzik dinlerim. Nakarat

Alışverişe ara sıra giderim.

Hafta sonları bazen balık tutarım.

Genellikle geceleri kitabımı okurum.

Sosyal hayatımı pek çok severim.

Çoğu zaman işime bisikletle giderim.

Ara sıra yürürüm, müzik dinlerim. Nakarat

Söz-Müzik: Nurdan Gürel

\section{SOSYAL ETKINLIKK}
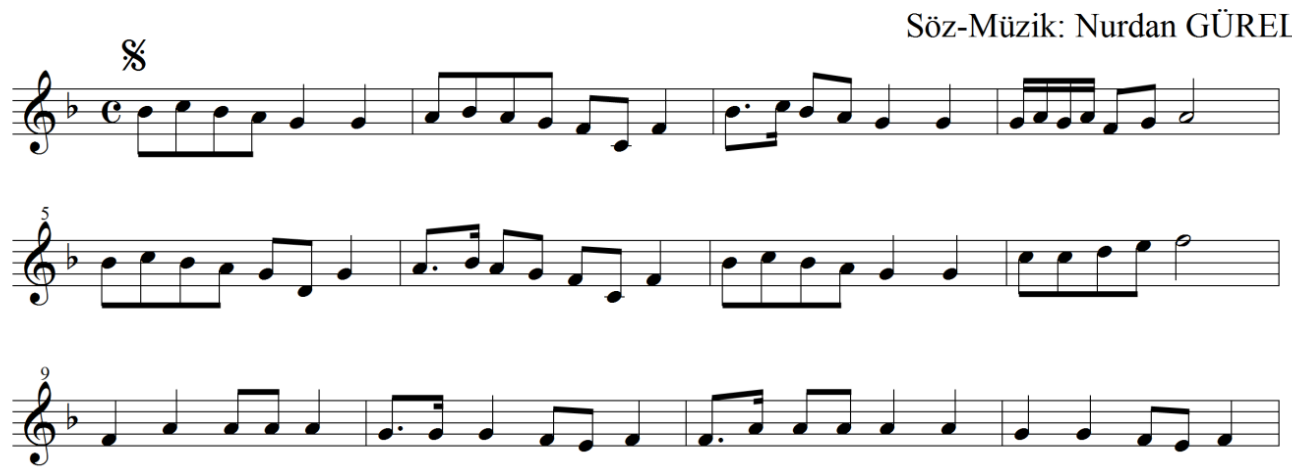

Film iz le me yi her za man se ve rim $\operatorname{Ar}$ ka daș la rım la hep film iz le rim

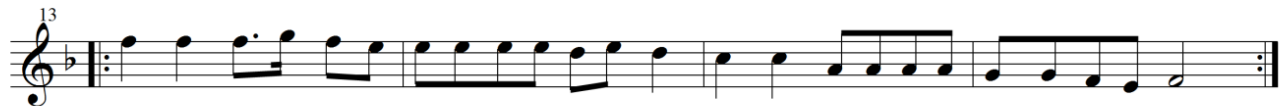

Ba zen kar de şim le ti yat ro ya gi de rim Sos yal ha ya tı mı pek çok se ve rim
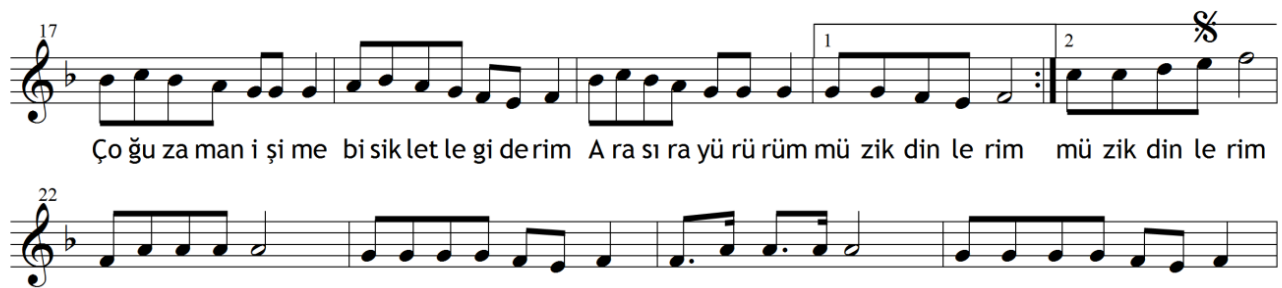

A lış ve ri şe a ra sı ra gi de rim Haf ta son la rı ba zen ba lık tu ta rım

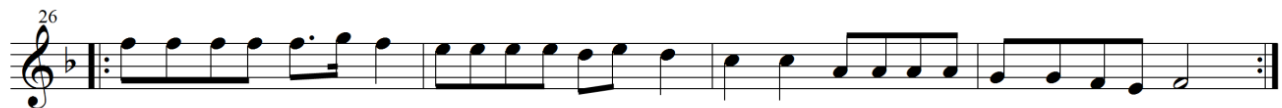

Ge nel lik le her ge ce ki ta bı mi o ku rum Sos yal ha ya tı mı pek çok se ve rim

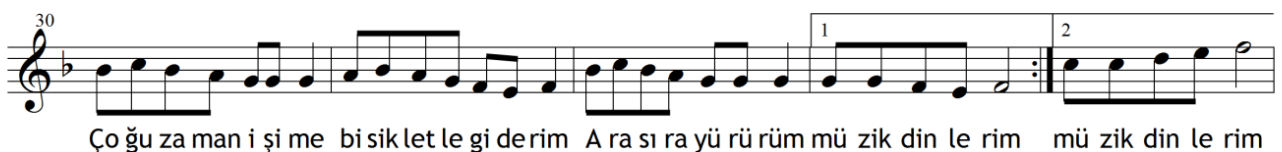


"Sosyal Etkinlik" adlı şarkı A2 öğrencileri hedeflenerek bestelenmiştir. Bu şarkıda tema olarak "Sosyal Etkinlikler" alt tema olarak da "Sinema-Tiyatro-Konser" seçilmiştir. Bu şarkıyı öğrenen yabancı öğrenciler, sinema- tiyatro- konser alt temasına ait kelimeleri ve bu kelimelerle birlikte cümle oluşturabilecekleri geniş zaman kalıplarını öğrenebileceklerdir. Şarkıdaki genel hedef ise öğrencilerin geniş zaman ifadelerini öğrenerek günlük hayatta konser, sinema, tiyatro vs. sosyal etkinlikleri ne sıklıkla yaptıklarını ifade edebilmelerini sağlamaktır. Öğrencilerin kelimeleri ve cümle kalıplarını akıllarında tutabilmeleri ve daha kolay öğrenebilmeleri için tekrar eden ifadelere (nakarat) ve şarkının melodisinin akılda kalıcı olmasına özen gösterilmiştir.

\section{Şarkı 4: Hava Durumu}

\begin{tabular}{|l|l|l|}
\hline \multicolumn{1}{|c|}{ Beceriler } & \multicolumn{1}{|c|}{ Dil Bilgisi } & \multicolumn{1}{c|}{ Kelimeler } \\
\hline $\begin{array}{l}\text { Hava durumu ile ilgili } \\
\text { kelimeleri öğrenir, } \\
\text { İsimden isim yapan çekim } \\
\text { eklerini öğrenir }\end{array}$ & -lı (- i, -u, -ü) & $\begin{array}{l}\text { yağmurlu, güneşli, firtınalı, } \\
\text { soğuk, 1llk, sisli, sağanak } \\
\text { yağmurlu, sıcak. }\end{array}$ \\
\hline
\end{tabular}

Tema: Hava Durumu

Dil Bilgisi: -l1 (- i,- u,- ü)

Amaç: Mevsimlere ait kelimeleri öğretmek.

\section{HAVA DURUMU (A1)}

Yağmur yağıyor, güneş açıyor.

Bulutlar hepimize 'merhaba' diyor.

Karlar yağıyor, hava soğuyor

Sonra güneş hepimize 'merhaba' diyor.

Yağmurlu havada, güneşli havada

Bulutlu havada, her zaman gülümseriz.

Sağanak yağmurda, firtınalı havada

Kışın soğukta havada her zaman gülümseriz (Nakarat)

Güneş doğuyor, sıcak oluyor

Bulutlar çıkıyor, 1lık oluyor

Karlar yağıyor, hava soğuyor

Sonra güneş hepimize 'merhaba' diyor.

Yağmurlu havada, güneşli havada

Bulutlu havada, her zaman gülümseriz.

Sağanak yağışta, firtınalı havada

Kışın soğukta havada her zaman gülümseriz (Nakarat)

Söz - Müzik: Nurdan Gürel 


\section{HAVA DURUMU}
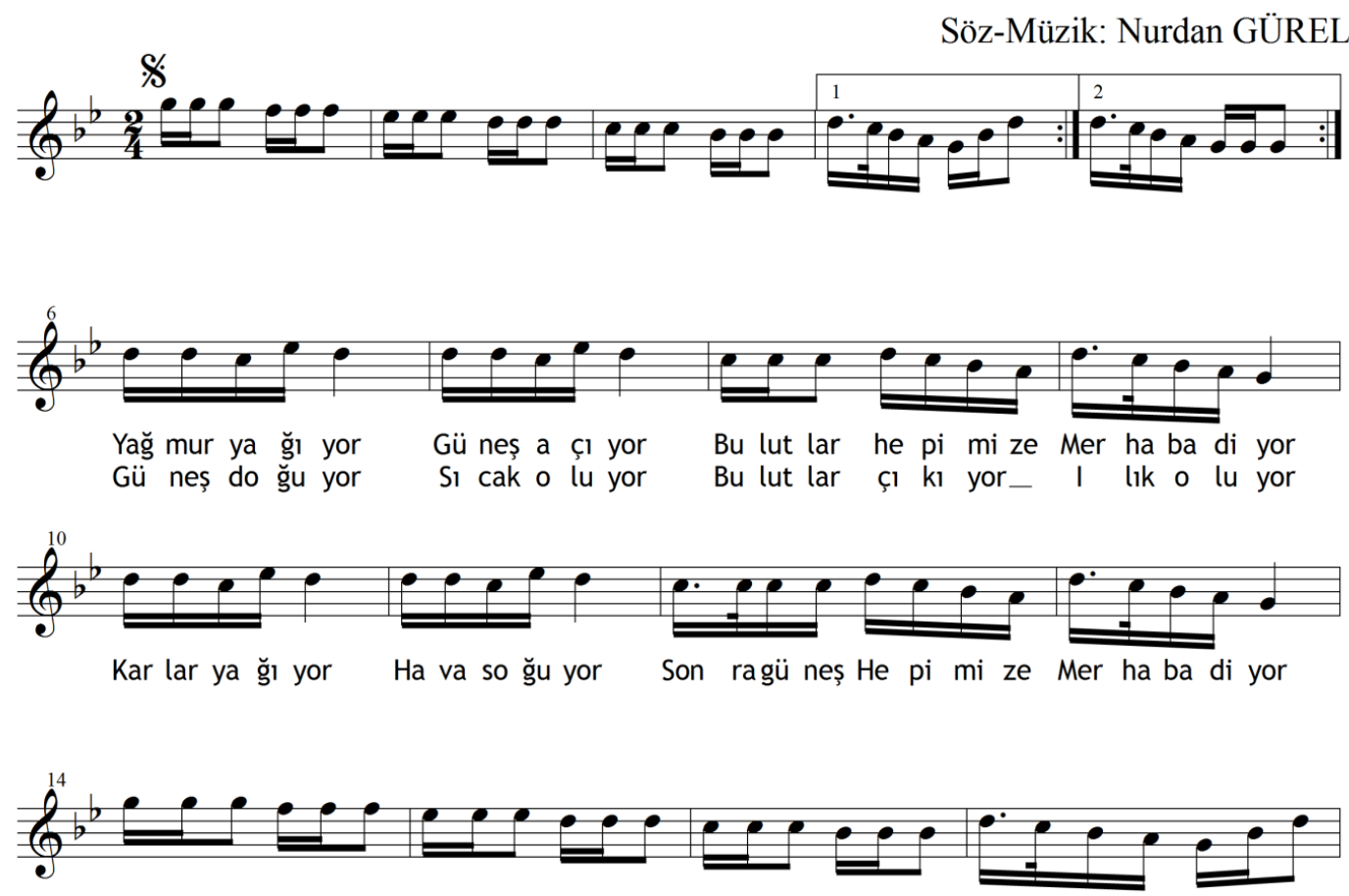

Yağ mur lu ha va da Gü neş li ha va da Bu lut lu ha va da Her za man gü lüm se riz

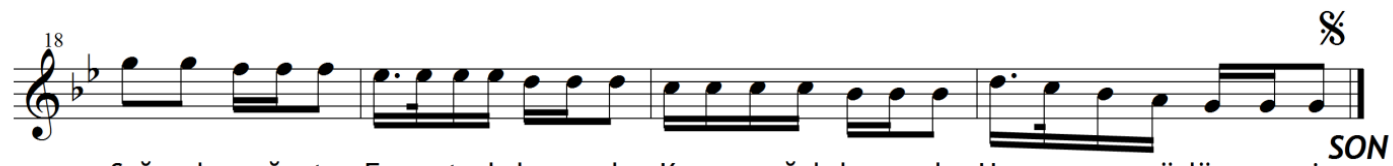

Sağ nak ya ğıș ta Fır nı ta lı ha va da $K_{\imath}$ șın so ğuk ha va da Her za man gü lüm ser riz

Hava Durumu adlı şarkıda A1 dil seviyesindeki öğrenciler hedeflenmiştir. Bu şarkıda hava durumu teması kullanılmıştır. Öğretilmesi, sezdirilmesi amaçlanan dil bilgisi konuları ise isimden isim yapım eklerinden -l1-li-lu-lü eklerini bulunma durumu çekim eklerinden -da, -de,-ta,-te ekleridir. Ayrica hava durumu ile ilgili kelimeleri (yağmur, güneş, firtına, soğuk, sıcak, 1lık, kış) ve kelime kalıplarını (sağanak yağmur, firtınalı hava, soğuk hava, güneş aç-, yağmur yağ- ) öğretmek de amaçlanmıştır. Öğrenci, şarkıyı öğrenip söyledikçe, ezberledikçe kelimelerin doğru telaffuzunu da öğrenecek ve bu durum öğrencilerin konuşma becerilerinin gelişimine katkı sağlayacaktır.

\section{Şarkı 5: Spor Yap, Sağlıklı Kal}

\begin{tabular}{|l|l|l|}
\hline \multicolumn{1}{|c|}{ Beceriler } & \multicolumn{1}{c|}{ Dil Bilgisi } & \multicolumn{1}{c|}{ Kelimeler } \\
\hline Spor alt teması ile ilgili bazı & ister... ister, hem... hem & sağlıklı, \\
kelimeleri öğretmek & dan (-den, -tan, -ten) /önce, sonra & spor, güçlü ol-, \\
İkilemelerin cümleye kattığı & -mak (-mek) için, & zinde kal-, \\
anlamı anlar, & koş-, \\
dan (-den, -tan,-ten)/önce, & & yürü-, \\
sonra dil bilgisi kalıbının & & yüz-, \\
cümleye kattığı anlamı fark & & zıpla-, \\
eder, & huzurlu, mutlu \\
-Mak (-mek) için, dil bilgisi & & \\
kalıbının cümleye kattığ1 & & \\
anlamı fark eder. & & \\
\hline
\end{tabular}

Tema: Sosyal Etkinlikler 
Alt Tema: Spor

Dil Bilgisi: ister... ister, hem... hem, -dan (-den, -ten, -tan) sonra/önce, -mak (-mek) için

SPOR YAP, SAĞLIKLI KAL (A2)

Sabah kalktıktan sonra

Akşam yatmadan önce

Mutlu, güçlü olmak için

Spor yap, sağlıklı kal.

Sağlikl1, huzurlu, mutlu olmak için

Spor yap ve zinde kal. (Nakarat)

Hem spor yap hem zinde kal

İster yürü, ister koş,

Hem spor yap hem zinde kal

İster yüz ister zıpla

Spor yap ve sağlıklı kal.

Sağlıklı, huzurlu, mutlu olmak için

Spor yap ve zinde kal. (Nakarat)

Söz - Müzik: Nurdan Gürel

Söz-Müzik: Nurdan GÜREL

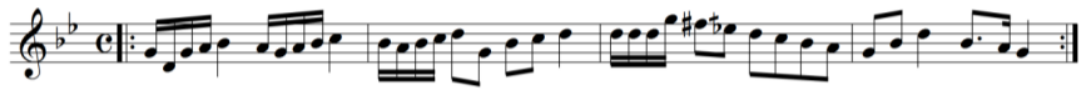

$\zeta^{5}$
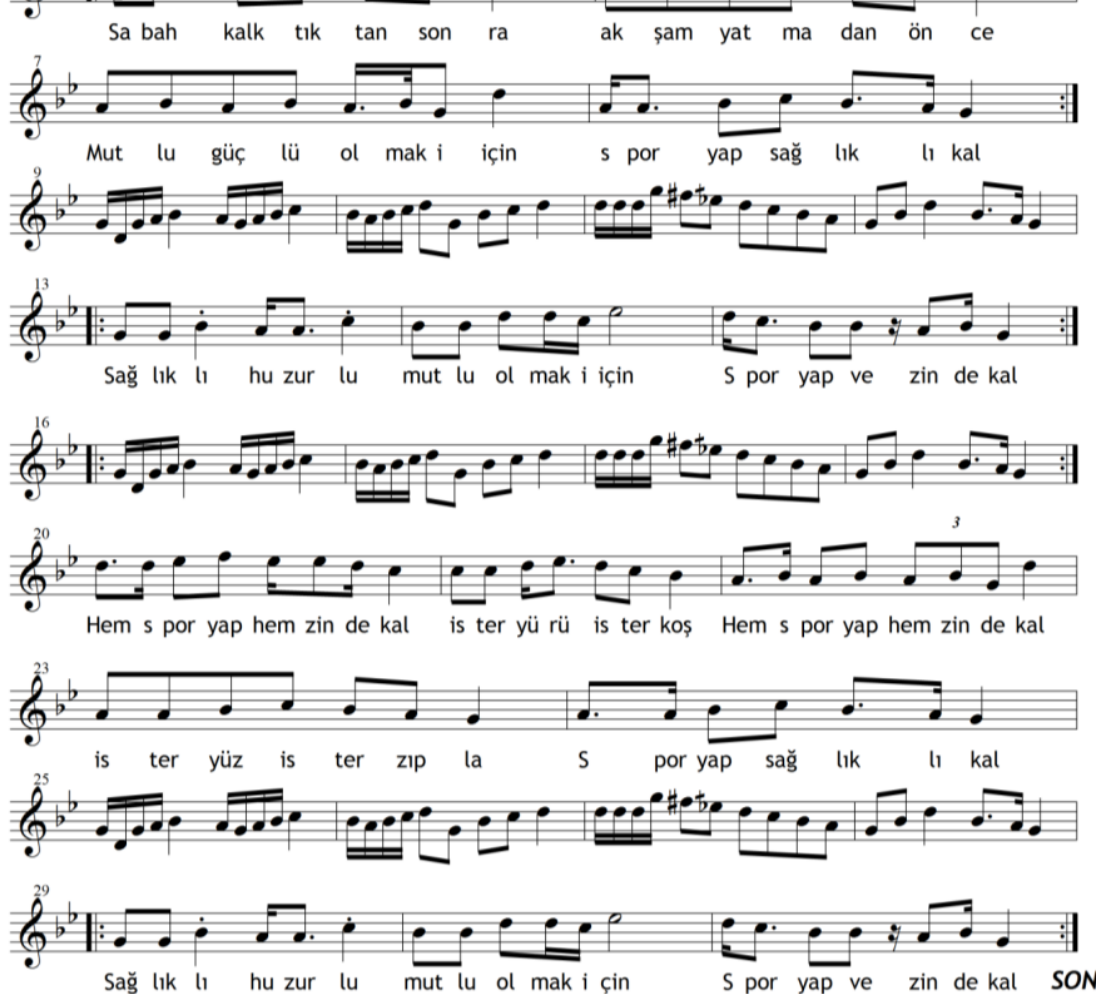
"Spor Yap Sağlıklı Kal” adlı şarkı A2 dil seviyesindeki öğrenciler için hazırlanmıştır. Şarkının genel teması sosyal etkinlikler, alt teması ise spordur. Spor ile ilgili bazı kelimelerin ve kelime kalıpların ve ikilemelerin cümle içinde nasıl kullanıldığının öğretilmesi amaçlanmıştır (hem... hem, ister... ister). Öğrencilerin iki ikileme arasındaki farkı amaca uygun olarak bu şarkı için hazırlanan etkinliklerin de yardımıyla öğrenmeleri ve -dan (-den,-ten,-tan) sonra/önce, -mak (-mek) için gibi dil bilgisi kalıplarının kelimelere ve cümlelere kattığı anlamı sezdirmek hedeflenmiştir.

\section{SONUÇ VE ÖNERILER}

$\mathrm{Bu}$ çalışmada, Türkçenin yabancı dil olarak öğretiminde kullanılmak üzere özgün bir materyal geliştirmek amaçlanmıştır. Bu amaca uygun olarak çalışmada bestelenen beş adet materyalden iki şark1 A1, diğer üç şarkı da A2 seviyesine uygun olarak hazırlanmış ve AOÖÇ'de belirtilen seviyelere uygun temalara göre işlenmiştir. Bu temalarla birlikte şarkıların her birinde, öğretilmesi hedeflenen dil bilgisi kuralları ve kelime kalıplarına yer verilmiştir. Şarkılarda işlenen temalar A1 seviyesinde; hava durumu, hobiler ve ilgi alanlarıdır. A2 düzeyinde ise sosyal etkinlikler ve alışveriştir. Sosyal etkinlikler teması iki şarkıda, sinema-tiyatro-konser ve spor alt temalarına göre bestelenmiştir. Temalar belirlenirken AOÖÇ’den yararlanılmıştır. Bestelenen şarkılarda kullanılan kelimelerin seviyelere uygun olup olmadığına dikkat edilmiş kullanılan kelimeler tek tek seçilmiştir. Tüm bu amaçlar doğrultusunda hazırlanan şarkılar uzman kişilerin de görüşleri alınarak yabancı öğrenciler üzerinde uygulanmıştır. Uygulama sonucunda yapılan gözlemler ve görüşleri alınan öğrencilerden elde edilen bulgular bu şekilde bir materyalle desteklenen derslerin öğrencilerin motivasyonlarını yüksek tuttuğu, dersi daha eğlenceli hâle getirdiği, öğrencilerin derste çok daha rahat olduğu ve derse aktif olarak katılmaktan çekinmediğini göstermiştir.

Şarkıların tekrara dayalı kalıplardan oluşması, akılda kalıcılığı artırmakta, böylece kullanılan kelimelerin hem telaffuzu hem de öğrenilmesi daha da kolaylaşmaktadır. Bu çalışmada elde edilen sonuçlar değerlendirildiğinde konulara, temalara yönelik amaçlı olarak bestelenen Türkçe şarkılar, Türkçenin yabancı dil olarak öğretilmesine katk1 sağlayabilmekte, özellikle kelimelerin telaffuzunun daha kolay öğrenilmesine yardımcı olabilmektedir. Çünkü amaçlanan dil bilgisi konularının veya kelimelerin şarkı içinde sürekli tekrar etmesi ve şarkılarda sadece amaca hizmet eden kelimelerin bulunması, şarkıların akılda kalıcılı olması da göz önünde alınırsa öğretimin daha kolay olabilmesine katkı sağlamaktadır.

Araştırmada ulaşılan sonuçlar doğrultusunda Türkçeyi yabancı dil olarak öğrenen öğrencilere daha verimli bir ders ortamı sunmak için bu alanda çalışan araştırmacılara şu önerilerde bulunulabilir:

1. Türkçenin yabancı dil olarak öğretimi için hazırlanan ders materyalleri öğrencilerin çeşitli duyularına yönelik ve öğrencilerin ilgilerini derste tutacak şekilde hazırlanmalı, hazırlanan materyallerde öğrencilerin dil seviyeleri dikkate alınmalıdır.

2. Türkçenin yabancı dil olarak öğretimi için hazırlanan başka bir beste çalışması bulunmamaktadır. Bunun gibi amaçlı hazırlanan şarkıların, hedef kitlenin derse olan ilgilerini canlı tutmak, öğrenimin daha akılda kalıcı olması adına önemlidir. Bu ve buna benzer çalışmalar yapılarak hazırlanan materyallerin amaca uygun olarak derslerde kullanılması sağlanmalıdır.

3. Bu çalışmada sadece A1 ve A2 dil seviyesindeki öğrenciler hedef alınmıştır. Diğer dil düzeyleri için de benzer çalışmalar gerçekleştirilebilir.

4. Araştırmada kullanılan şarkılar çeşitlendirilerek aynı konu veya temalarda başka beste çalışmaları ve etkinlikleri yapılabilir. Hazırlanan etkinlikler daha da farklılaştırılabilir.

Bilgilendirme / Acknowledgement: Bu makale, Doç. Dr. Deniz Melanlığlu danışmanlığında hazırlanan aynı başlıklı yüksek lisans tezinin verilerinden yararlanarak hazırlanmıştır. 


\section{KAYNAKÇA}

Açık, F. ve Demir, A. (2011). Türkçenin Yabancı Dil Olarak Öğretiminde Kültürlerarası Yaklaşım ve Seçilecek Metinlerde Bulunması Gereken Özellikler, TÜBAR, (30), 51-72.

Ataseven, F. (1988). Değişen sınıf içi öğretim ortamları ve şarkılarının yabancı dil öğretiminde araç olarak kullanılması. Hacettepe Üniversitesi Eğitim Fakültesi Dergisi, 3(3), 189-198.

Barın, E. ve Güzel, A. (2013). Yabancı dil olarak Türkçe öğretimi. Ankara: Akçağ Yayınları.

Chen, Y. C. ve Chen, P. C. (2009). The effect of English popular songs on learning motivation and learning performance. WHAMPOA- An Interdisciplinary Journal 56, 13-28.

Dunlap, J. C. \& Lowenthal, P. R. (2010). Hot for teacher: Using digital music to enhance students' experience in online courses. Techtrends, 54(4), 58-73.

Gökşenli Y. E. (2012). Yabanc1 dil olarak İspanyolca öğretiminde müziğin öğretim aracı olarak kullanımı. Dergi Park Akademik Dergisi, 6, 13-43.

Güney, N., Aytan, T. ve Şengül, M. (2014). Müziksel-ritmik zekâya yönelik etkinliklerin dil bilgisi öğretiminde akademik başarıya etkisi. E-Journal of New World Sciences Academy, 9(2), 120-134.

Güngör, Y. Z. (2014). Yabancı dil öğretiminde şarkıların kullanımı: Fransız dili eğitimi bölümü öğrencileriyle bir uygulama. Humanitas, 2(4), 141-151.

Iudin, L. ve Nelson, J. (1997). Songs in the L2 syllabus: Integrating the study of Russian language and culture. Madison, Diss. U Of Wisconsin.

Kömür, Ş., Saraç, G., Şeker, H. (2005). Teaching English through songs. Muğla Üniversitesi Sosyal Bilimler Enstitüsü Dergisi (ILLKE), 1(15), 109-120.

Köse, B. (2012). Yabancı dil öğretiminde şarkı kullanımı. Yayınlanmamış yüksek lisans tezi, Çukurova Üniversitesi, Sosyal Bilimler Enstitüsü, Fransız Dili Eğitimi Ana Bilim Dalı, Adana.

Lacorte, M. ve Thurston, H (2000). Music in the foreign language classroom: Developing linguistic and cultural proficiency. 12 Kasim 2016 tarihinde www.dickinson.edu/prorg/nectfl/reviewarticles/49-lacorte.pdf adresinden erişildi.

Maess, B., Koelsch, S., Gunter, T. C. ve Friederici, A. D. (2001). Musical syntax is processed in the area of Broca: An MEG study. Nature Neuroscience, 4, 540-545.

Milli Eğitim Bakanlığı. (2009). Diller için Avrupa ortak başvuru metni öğrenme - öğretme değerlendirme. Ankara: MEB Talim ve Terbiye Kurulu Başkanlığı.

Nişancı, İ. (2013). Türkçe şarkıların dil öğretiminde kullanımı. UTEK, Albania.

Temiz, E. (2011). Çocukların müziksel ses özelliklerine uygun şarkı söyleyebilme becerilerine işitme kaybı değişkeninin etkisi. İönü Üniversitesi Sanat ve Tasarım Dergisi, 1(1), 67-75.

Yustiana, E. (2009). Teaching English using song to improve student's pronunciation in PG and TK. Unpublished Research Paper for Getting Bachelor Degree of Education in English Department, Muhammadiyah University of Surakarta. 